\title{
Effect of Glomus fasciculatum on the Growth of Asparagus and the Incidence of Fusarium Root Rot
}

\author{
Tracy L. Wacker, Gene R. Safir, and Christine T. Stephens \\ Department of Botany and Plant Pathology, Michigan State University, East Lansing, MI 48824
}

\begin{abstract}
Additional index words. mycorrhizal fungus, Asparagus officinalis, Fusarium oxysporum
Abstract. Asparagus (Asparagus officinalis L.) seedlings inoculated with the sicular-arbuscular mycorrhizal (VAM) fungus Glomus fasciculatum (Thaxt. sensu Gerd.) Gerd. \& Trappe (GF) d Fusarium oxysporum (Schlect.) Snyd. \& Hans. (FO) were grown under field and greenhouse conditions. In the fi , shoot volumes of GF-inoculated plants were greater than nonGF plants from the 3rd through the 13th month of growth. By the 14th month, GF-inoculated plants grown in high-P soils had significantly lower disease ratings than nonGF plants grown in low-P soils, and rhizosphere populations of FO were lowest in high-P soils, regardless of VAM status. In greenhouse studies, FO inoculation of VAM-infected asparagus plants reduced GF root colonization levels under well-watered (0 MPa), but not under water stress, conditions ( $-1.5 \mathrm{MPa}$ ). Well-watered plants inoculated with both FO and GF were less diseased and sustained lower rhizosphere populations of FO than plants inoculated with FO alone. The differences in FO populations and disease ratings in these studies were apparently unrelated to final plant tissue $P$ levels.
\end{abstract}

Asparagus seedlings respond to inoculation with VAM fungi in controlled environments (Chang, 1985; Hussey et al., 1984; Powell et al., 1985) and in the field (Powell and Bagyaraj, 1983). Evans et al. (1985) found that P levels were lower in the roots of asparagus plants grown in fumigated soils in the absence of VAM fungi than in roots grown in non fumigated soils. Low P levels, coupled with low VAM colonization in asparagus planted in fumigated soils, suggests that asparagus may have a high mycorrhizal dependency, at least in the seedling stage.

Asparagus suffers from an overall field decline, resulting in decreased yield, plant vigor, and longevity (Grogan and Kimble, 1959). Although environmental and physical stresses predispose the host to pathogen invasion (Hoddupp, 1983; Takatori et al., 1970, 1,974), the ultimate cause of plant death is attributed to the root and crown rot organisms FO and Fusarium moniliforme (Sheld.) Snyd. \& Hans., respectively (Damicone and Manning, 1985; Endo and Burkholder, 1971; Graham, 1955; Johnston et al., 1979; VanBakel and Kerstems, 1970).

There have been numerous studies involving interactions between VAM fungi and fungal root pathogens on several host plants with varying results. For example, VAM fungal inoculation has been shown to decrease (Zambolim and Schenck, 1983; Caron et al., 1985, 1986a, 1986b, 1986c), increase (Davis et al., 1979), or have no effect (Schönbeck and Dehne, 1977) on pathogen-induced plant disease severity or pathogen development. Of particular interest are the recent findings that inoculation of tomato seedlings with the VAM fungus Glomus intraradices decreased root necrosis caused by FO f. sp. radicislycopersici (Caron et al., 1985). These effects were apparently not related to the sequence of inoculation with the two fungi (Caron et al., 1986a) or to increased levels of soils or plant tissue P levels (Caron et al., 1986b).

The first objective of the present work was to determine if inoculation of asparagus seedlings with the VAM fungus GF

\footnotetext{
Received for publication 31 Mar. 1989. We acknowledge the Michigan Agricultural Experiment Station for supporting this research and thank John Bakker and Margaret Vierbüchen for their technical assistance. The cost of publishing this paper was defrayed in part by the payment of page charges. Under postal regulations, this paper therefore must be hereby marked advertisement solely to indicate this fact.
}

and the pathogen FO would affect the growth of asparagus and disease development in the field at two soil P levels. The second objective was to study, in the greenhouse, the same fungal interaction in relation to water availability at a soil $\mathrm{P}$ level predetermined to yield similar plant growth responses in mycorrhizal and nonmycorrhizal plants.

\section{Materials and Methods}

Field study. The field plot (located at the Asparagus Research Farm in Hart, Mich.; Spinks sandy loam, $\mathrm{pH}=7.0$, soil $\mathrm{P}_{2} \mathrm{O}_{5}$ $\left.=185 \mu \mathrm{g} \cdot \mathrm{g}^{-1}\right)$ was deep-tilled $(30 \mathrm{~cm}$ depth) and fumigated with methyl bromide $\left(\mathrm{MeBr}_{2}\right)$ at $448 \mathrm{~kg} \cdot \mathrm{ha} \mathrm{a}^{-1}$ in Sept. 1985. Seeds of rye (Secale cereale L.) were surface-sterilized with a $0.5 \%$ sodium hypochlorite solution (10\% household bleach) for 30 min and broadcast over the entire field to form a dense cover crop. The rye was treated with glyphosate (RoundUp, Monsanto Co., St. Louis) at 0.4 liter-ha-1 in May 1986 and incorporated to increase the soil organic matter. Nitrogen $\left[\mathrm{CO}\left(\mathrm{NH}_{2}\right)_{2}\right.$, granular] and potassium $\left(\mathrm{K}_{2} \mathrm{O}\right.$, granular) were broadcast to attain elemental soil levels of 38 and $73 \mu \mathrm{g} \cdot \mathrm{g}^{-1}$, respectively. Phosphorus $\left(\mathrm{P}_{2} \mathrm{O}_{5}\right.$, granular) was added to the appropriate treatments; final soil $\mathrm{P}\left(\mathrm{P}_{2} \mathrm{O}_{5}\right.$, Bray's $\mathrm{P}-1$ extractable) levels were either $185(-\mathrm{P})$ or $350 \mu \mathrm{g} \cdot \mathrm{g}^{-1}(+\mathrm{P})$. The experiment was set up as a $2 \times 2$ factorial $( \pm \mathrm{P} ; \pm \mathrm{GF})$ in a randomized completeblock design with three replications.

Preparation of inoculum. Inoculum of GF was obtained by adding chlamydospores of the fungus to pot cultures of sorghum (Sorghum vulgare Pers.). The GF-infested soil and sorghum roots were harvested after 4 months and stored at $4 \mathrm{C}$ for 4 months before use. Spores were isolated from soil samples by wet-sieving and a modification of Ohms' (1957) centrifugationflotation technique. The number of spores per soil sample was obtained by counting spores under a dissecting microscope. Inoculum (spore) levels ranged from 50 to 70 spores per gram of soil.

An isolate of virulent FO (F10; from the collection of M. Lacy, Michigan State Univ., East Lansing) that had been main-

Abbreviations: FO, Fusarium oxysporum (Schlect.) Snyd. \& Hans.; GF, Glomus fasciculatum (Thaxt. sensu Gerd.) Gerd. \& Trappe; VAM, vesicular-arbuscular mycorrhizal. 
tained in soil (Nelson et al., 1983) was cultured on potato dextrose agar at room temperature (20C) for 7 days. Millet seed $(200 \mathrm{~g})$ was placed in 1-liter Erlenmyer flasks with $100 \mathrm{ml}$ of distilled water and autoclave for $1 \mathrm{hr}$ at $121 \mathrm{C}$ on 2 consecutive days. When cool, the flasks were shaken vigorously to eliminate large clumps of millet seed. One 4-mm-diameter plug of FOinfested agar was added to each flask. Flasks were shaken every day to facilitate distribution of the fungus. After 14 days, the millet seed was allowed to dry at room temperature for 6 days (Stephens et al., 1985).

Field-inoculation. FO-infested millet seed (15 g) was placed in the field in rows at $30-\mathrm{cm}$ intervals at a depth of $10 \mathrm{~cm}$; all treatments received FO. Either $5 \mathrm{~g}$ of soil containing GF inoculum or $5 \mathrm{~g}$ of sterile GF soil (autoclave for $1 \mathrm{hr}$ on 2 consecutive days) was added with the FO inoculum in both $\mathrm{P}$ treatments.

Seedling preparation and field transplantation. Asparagus seeds ('UC 157') were surface-sterilized in benomyl : acetone as described by Damicone et al. (1981). Seeds were germinated on sterile, moistened filter paper. Seven days later, germinated seeds were placed in flats containing Baccto greenhouse mix (1 vermiculite : 1 peat : 1 perlite, by volume; Michigan Peat Co., Houston). Before seed placement, either $5 \mathrm{~g}$ of GF inoculum or $5 \mathrm{~g}$ of sterile GF soil (as described above) plus $1 \mathrm{ml}$ of inoculum wash was added to the soil mix in the flats. The inoculum wash (prepared by wet-sieving inoculum soil through a $38-\mu \mathrm{m}$ sieve to eliminate VAM fungal propagules) consisted of microbes associated with the inoculum soil and was added to both mycorrhizal and nonmycorrhizal treatments. After 1 month, the asparagus was transplanted into 10-cm-diameter (500 $\mathrm{cm}^{3}$ ) clay pots containing the same growth medium (one plant/ pot). Plants were fertilized every 2 weeks with a $100-\mathrm{ml}$ solution containing $\mathrm{N}, \mathrm{P}$, and $\mathrm{K}$, each at $100 \mu \mathrm{g} \cdot \mathrm{ml}^{-1}$, and watered as needed. Asparagus plants (4 months old) were transplanted to the field on 14 June 1986 and placed directly over the FO and GF inocula.

Collection and analysis of field data. Shoot heights and diameters were measured monthly (July-Sept. 1986 and MayAug. 1987) and above-ground volumes were calculated from these data. Plants were harvested in Sept. 1986 and Aug. 1987, 3 and 14 months, respectively, after they were transplanted in the field. Eight plants/block were harvested from each treatment and rated according to the percent root area affected by lesion development or discoloration (reddening) caused by FO $(1=$ $0 \%$ to $10 \%, 2=11 \%$ to $20 \%, 3=21 \%$ to $30 \%, 4=31 \%$ to $40 \%$, and $5=$ more than $40 \%$ of the roots affected). The percent of VAM fungal root colonization was evaluated. Roots were removed $(0.5 \mathrm{~g} / \mathrm{plant})$ at random and stained with acid fuchsin in lactophenol (modified from Phillips and Hayman, 1970). Root segments (1 cm length) were placed on slides for observation using light microscopy. There were 60 segments per treatment. Segments were rated for VAM fungal infection, where $1=$ no infection, $2=1 \%$ to $25 \%$ of the segment infected, $3=25 \%$ to $50 \%, 4=50 \%$ to $75 \%$, and $5=$ more than $75 \%$ infection. Fresh and dry (48 $\mathrm{hr}$ at 100C) weights were obtained and dried tissue was assayed for P concentration (Bartlett, 1959). Data were subjected to analysis of variance and an LSD mean separation test. The field experiment was repeated for the first 4 months in 1987. All of the significant differences observed in the first field experiment were seen in the repeated experiment.

Greenhouse study. The experiment was set up as a $2 \times 3$ factorial (two soil water potentials, $\pm \mathrm{GF}, \pm \mathrm{FO}$ ) in a com- pletely randomized design with 15 single plant replications per treatment. A 2 sand : 1 soil mixture (v:v, $\mathrm{pH} 7.0$ ) was steamsterilized for $24 \mathrm{hr}$ and amended with $125 \mu \mathrm{g}$ elemental $\mathrm{P} / \mathrm{g}$ of soil (added as $\mathrm{Ca}_{2} \mathrm{H}_{2} \mathrm{PO}_{4}$ ); $500 \mathrm{~g}$ of this mix was added to each 10 -cm-diameter $\left(500 \mathrm{~cm}^{3}\right)$ pot. Either $1 \mathrm{~g}$ of GF inoculum (as described above) or $1 \mathrm{~g}$ of sterile inoculum soil was placed 5 $\mathrm{cm}$ below the soil surface in a depression made at time of transplanting. Inoculum wash (1 $\mathrm{ml} /$ pot, as described previously) was added to both GF and nonGF treatments.

Eight-week-old asparagus plants ('UC 157') were transplanted from a Baccto mix into the prepared soil (one plant/ pot). Before transplanting, the plants were fertilized weekly with $100 \mathrm{ml}$ of $100 \mu \mathrm{g} \mathrm{N}, \mathrm{P}$, and $\mathrm{K} / \mathrm{ml} \mathrm{H}_{2} \mathrm{O}$ and watered as needed. Each treatment was then split and either watered well (container capacity, $0 \mathrm{MPa},+\mathrm{GF})$ or water-stressed $(-1.5 \mathrm{MPa}, \pm \mathrm{VAM})$. The soil matric potential was never below -0.2 in the wellwatered pots or $-1.5 \mathrm{MPa}$ in water-stressed treatments. Soil matric potentials were maintained by weighing the pots daily and bringing them to the required weights for that water potential. These weights were determined previously by obtaining the soil moisture curve for the 2 sand : 1 soil mix using a soil pressure plate (Soilmoisture Equipment Co., Santa Barbara, Calif.). The plants were fertilized with $100 \mathrm{ml}$ of $100 \mu \mathrm{g} \mathrm{N}, \mathrm{P}$, and $\mathrm{K} / \mathrm{ml} \mathrm{H}_{2} \mathrm{O}$ each week for the duration of the experiment.

Inoculum of FO (isolate F10) was prepared by adding F10, maintained in soil, to Komada's selective medium (Komada, 1975). Cultures of FO were incubated at $21 \mathrm{C}$ for 28 days. Conidia were removed from the surface of the plates by rinsing with sterile, glass-distilled water. The conidia were dislodged, and the collected suspension diluted with sterile, glass-distilled water to a concentration of $2 \times 10^{4}$ conidia/ml, with a ratio of 7 microconidia to 1 macroconidium (enumerated with a hemacytometer). The plants were inoculated 4 weeks after GF inoculation with either $1 \mathrm{ml}$ of sterile, glass-distilled water (-FO) or $1 \mathrm{ml}$ of the conidial suspension $(+\mathrm{FO})$ by inserting a hypodermic needle just beneath the crown of the plant.

Plants were harvested 8 weeks after inoculation with FO (4 months old) and rated for disease severity and VAM fungal colonization (as described above). Fresh and dry (24 hr at 100C) weights were obtained and dry tissue was assayed for P concentration. The data were subjected to analysis of variance and Student-Newman-Keuls mean separation test. This experiment was repeated once, and this experimental replication was included as a factor in the analysis reported herein.

\section{Results}

Field study. All treatments were uniformly mycorrhizal- and FO-infected by the 3rd month (Table 1). Mycorrhizal root colonization was greatest in $\mathrm{P}$ soils by the 14th month and was significantly different between $+\mathrm{GF}-\mathrm{P}$ treatments and $+\mathrm{P}$ treatments $(P<0.05)$. Tissue $\mathrm{P}$ levels were not significantly different among treatments harvested the 3rd month (Table 1), but were highest $(P=0.05)$ in $-\mathrm{GF}$ plants grown in low soil $\mathrm{P}\left(185 \mu \mathrm{g} \cdot \mathrm{g}^{-1}\right)$ by the 14 th month.

Growth of +GF plants was generally greater than that of -GF plants, as measured by fresh weights in 1986 (3 months) and dry weights in 1987 (14 months) (Table 1). Shoot volumes of $+\mathrm{GF}$ asparagus plants were significantly greater than those of -GF plants from the 2nd to the 3rd month of growth (Fig. 1). In addition, during the 1lth and 12th months, mycorrhizal plants grown at low soil $\mathrm{P}$ had significantly greater shoot volumes than all other treatments $(P=0.01)$. By the 13 th month, these differences were no longer present. 
Table 1. Effect of GF infection and supplementary soil $P$ on growth of asparagus grown in the field in the presence of FO and on infection characteristics. Values within columns and within the same year that are followed by the same letter are not significantly different at $P=$ 0.05 (LSD mean separation test).

\begin{tabular}{|c|c|c|c|c|c|c|c|c|}
\hline Treatment & $\begin{array}{l}\text { VAM } \\
\text { rating }\end{array}$ & $\begin{array}{l}\text { Tissue } \mathrm{P} \\
(\% \text { dry wt) }\end{array}$ & Fresh wt $(\mathrm{g})$ & Dry wt $(\mathrm{g})$ & Shoots/plant & $\begin{array}{l}\text { Root : shoot } \\
\text { ratio }\end{array}$ & $\begin{array}{c}\mathrm{FO} \\
\text { rating }\end{array}$ & $\begin{array}{c}\mathrm{FO} \\
\text { populations }^{\mathrm{x}}\end{array}$ \\
\hline \multicolumn{9}{|c|}{$1986(3 r d$ month $)$} \\
\hline$-G F-P$ & $2.7 \mathrm{a}$ & $0.4 \mathrm{a}$ & $444 \mathrm{c}$ & --- & $8.7 \mathrm{~b}$ & --- & $1.9 \mathrm{a}$ & $17.5 \mathrm{a}$ \\
\hline$-G F+P$ & $2.8 \mathrm{a}$ & $0.3 \mathrm{a}$ & $614 \mathrm{bc}$ & --- & $10.5 \mathrm{ab}$ & -- & $2.2 \mathrm{a}$ & $18.3 \mathrm{a}$ \\
\hline$+\mathrm{GF}-\mathrm{P}$ & $2.6 \mathrm{a}$ & $0.4 \mathrm{a}$ & 923 a & --- & $12.9 \mathrm{a}$ & -- & $1.9 \mathrm{a}$ & $13.9 \mathrm{a}$ \\
\hline$+\mathrm{GF}+\mathrm{P}$ & $2.7 \mathrm{a}$ & $0.2 \mathrm{a}$ & $785 \mathrm{ab}$ & --- & $11.7 \mathrm{ab}$ & -- & $2.1 \mathrm{a}$ & $17.2 \mathrm{a}$ \\
\hline \multicolumn{9}{|c|}{1987 (14th month) } \\
\hline$-G F-P$ & $2.0 \mathrm{ab}$ & $0.5 a$ & $834 \mathrm{a}$ & $303 \mathrm{~b}$ & $11.1 \mathrm{a}$ & $1.23 \mathrm{a}$ & $2.2 \mathrm{a}$ & $49.9 \mathrm{ab}$ \\
\hline$-G F+P$ & $1.8 \mathrm{~b}$ & $0.3 \mathrm{~b}$ & 817 a & $297 \mathrm{~b}$ & $11.0 \mathrm{a}$ & $1.19 \mathrm{ab}$ & $1.6 \mathrm{ab}$ & $39.1 \mathrm{c}$ \\
\hline$+\mathrm{GF}-\mathrm{P}$ & $2.1 \mathrm{a}$ & $0.4 \mathrm{~b}$ & 907 a & $322 a b$ & $11.2 \mathrm{a}$ & $0.99 \mathrm{ab}$ & $1.8 \mathrm{ab}$ & $52.7 \mathrm{a}$ \\
\hline$+\mathrm{GF}+\mathrm{P}$ & $1.9 \mathrm{~b}$ & $0.3 \mathrm{~b}$ & $1002 \mathrm{a}$ & 398 a & $8.1 \mathrm{a}$ & $0.98 \mathrm{~b}$ & $1.5 \mathrm{~b}$ & $39.6 \mathrm{bc}$ \\
\hline
\end{tabular}

${ }^{2}$ VAM rating of asparagus root segments. Values range from 1 (no infection) to 5 (>75\% of root segment infected).

'Rating system ranges from 1 to 5 and reflects the percentage of the root system affected by lesions or reddening.

$\mathrm{x}$ (Number of propagules/g of soil +0.5$)^{1 / 2}$.

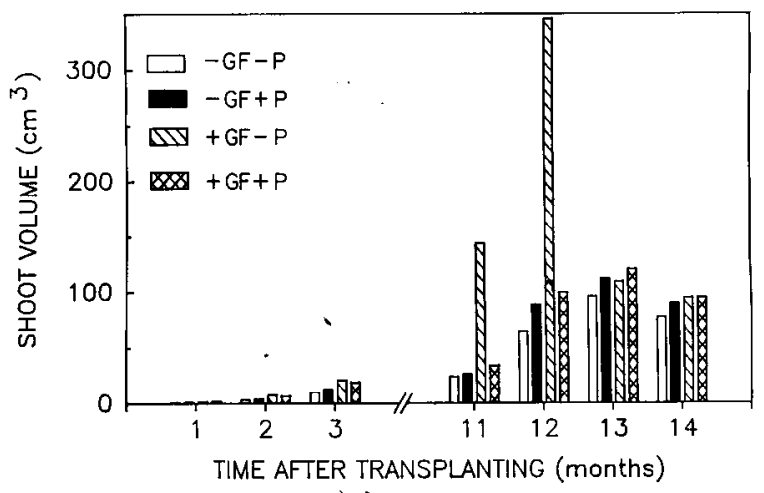

Fig.1. The effect of GF and supplementary soil $\mathrm{P}$ on shoot volumes of asparagus plants grown in the field (1986) in the presence of FO. $-\mathrm{GF}$, without G. fasciculatum; $+G F$, G. fasciculatum added; $-\mathrm{P}$, no phosphorus added to the soil $\left(185 \mu \mathrm{g} \mathrm{P}_{2} \mathrm{O}_{5} / \mathrm{g}\right) ;+\mathrm{P}$, additional soil phosphorus $\left(350 \mu \mathrm{g} \cdot \mathrm{g}^{-1}\right)$.

The numbers of shoots per plant were similar among the treatments throughout both growing seasons, except that $+\mathrm{GF}-\mathrm{P}$ plants had significantly more shoots than -GF-P plants in the 3rd month (Table 1). Significant differences in root : shoot ratios were found only between $+\mathrm{GF}+\mathrm{P}$ plants and $-\mathrm{GF}-\mathrm{P}$ plants $(P<0.05,14$ th month $)$.

By the end of the 14th month, $+\mathrm{GF}+\mathrm{P}$ plants had lower disease ratings than $-\mathrm{GF}-\mathrm{P}$, all other treatments were not significantly different (Table 1). Also in the 14th month, the rhizosphere of $+\mathrm{GF}-\mathrm{P}$ plants had more $\mathrm{FO}$ propagules per gram of soil than those in $-\mathrm{GF}+\mathrm{P}$ or $+\mathrm{GF}+\mathrm{P}$ plots, whereas $+\mathrm{P}$ soils tended to contain the fewest $\mathrm{FO}$ propagules per gram of soil in 1987 (14 months in the field) (Table 1).

Greenhouse study. Under well-watered conditions, both fresh and dry weights of +GF-FO were higher than those of -GF-FO plants (Table 2). Mycorrhizal plants tended to have lower dry weights under water-stressed than under well-watered conditions. Dry weights of -GF plants were unaffected by the water-stress treatment.

Mycorrhizal colonization was significantly lower in wellwatered, FO-inoculated treatments than the other three +GF treatments (Table 2). Tissue $\mathrm{P}$ concentration was slightly, but significantly, higher in water-stressed, +GF treatments than in, any well-watered pots. Well-watered plants inoculated with FO alone had more root lesions than any other FO-inoculated treatments (Table 2). Among the well-watered treatments, there were significantly fewer root lesions in +GF plants than in -GF plants when both were FO-inoculated. Disease ratings did not differ significantly in water-stressed treatments, regardless of GF or FO inoculation. The number of FO propagules per gram of soil was significantly higher in well-watered, - GF+FO treatments than in all other treatments.

\section{Discussion}

Our results indicate that asparagus seedlings respond favorably to mycorrhizal inoculation. The increased growth in the field after 3 months (Fig. 1, Table 1) and in the greenhouse under adequate soil moisture (Table 2) supports the findings of previous researchers (Chang, 1985; Hussey et al., 1984; Powell and Bagyaraj, 1983; Powell et al., 1985). The growth difference between plants inoculated with GF and noninoculated plants was less pronounced in the field after 14 months (Fig. 1, Table 1), although mycorrhizal plants grown in high-P soils still tended to have greater dry weights and lower FO ratings and propagule densities than all other treatments, possibly because all plants had become colonized by indigenous mycorrhizal fungi by the end of the first growing season. An analysis of spores isolated from these sites indicated that Glomus aggregatum was the most prominent naturally occurring VAM fungus. However, Hussey et al. (1984) found that VAM fungi indigenous to asparagus fields in Ontario, Canada, were less stimulator to growth of asparagus than those inoculated with a single VAM fungal species. In addition, greenhouse inoculation with mycorrhizal fungi, which were isolated from Michigan asparagus fields, did not stimulate growth in several host crops, including asparagus (T.L.W., unpublished data). It is possible that soil $\mathrm{P}$ level $\times$ FO interactions are more significant than VAM $\times$ FO interactions, as suggested in Table 1 . However, since all plants had become mycorrhizal (indigenous VAM fungal species colonizing roots would introduce a new variable: VAM $\times$ VAM fungal interactions), we cannot rule out the potential effect of VAM fungi on FO populations and disease levels.

The shoot volume reductions in mycorrhizal plants (low soil P) after the 13th month is partially due to cultivation injury and invasion of the test plots by $F$. moniliforme. The rapidly growing shoots of VAM-colonized plants were damaged by cultivation because of encroachment of fern (shoot) into between- 
Table 2. Effect of GF and FO infections on growth of asparagus and on infection characteristics in the greenhouse at two soil matric potentials. Values within columns followed by the same letter are not significantly different at $P=0.05$ (Student-Newman-Keuls mean separation test).

\begin{tabular}{|c|c|c|c|c|c|c|}
\hline Treatment & Fresh wt $(\mathrm{g})$ & Dry wt $(\mathrm{g})$ & $\begin{array}{l}\text { VAM } \\
\text { rating }\end{array}$ & $\begin{array}{l}\text { Tissue P } \\
\text { (\% dry wt) }\end{array}$ & $\begin{array}{l}\text { FO } \\
\text { ratingy }\end{array}$ & $\underset{\text { populations }}{\mathrm{FO}}$ \\
\hline \multicolumn{7}{|c|}{$O M P a$} \\
\hline$-\mathrm{GF}-\mathrm{FO}$ & $32.1 \mathrm{c}$ & $7.9 \mathrm{bc}$ & $1.0 \mathrm{c}$ & $0.2 \mathrm{~b}$ & $1.0 \mathrm{c}$ & -- \\
\hline$-\mathrm{GF}+\mathrm{FO}$ & $38.6 \mathrm{abc}$ & $8.8 \mathrm{abc}$ & $1.0 \mathrm{c}$ & $0.2 \mathrm{~b}$ & $2.7 \mathrm{a}$ & $39.8 \mathrm{a}$ \\
\hline$+\mathrm{GF}-\mathrm{FO}$ & $44.3 \mathrm{a}$ & $10.3 \mathrm{a}$ & $2.6 \mathrm{a}$ & $0.2 \mathrm{~b}$ & $1.0 \mathrm{c}$ & -- \\
\hline$+\mathrm{GF}+\mathrm{FO}$ & $40.9 \mathrm{ab}$ & $9.6 \mathrm{ab}$ & $1.8 \mathrm{~b}$ & $0.2 \mathrm{~b}$ & $2.1 \mathrm{~b}$ & $8.3 \mathrm{~b}$ \\
\hline \multicolumn{7}{|c|}{$-1.5 \mathrm{MPa}$} \\
\hline$-\mathrm{GF}-\mathrm{FO}$ & $36.1 \mathrm{~b}$ & $8.0 . b c$ & $1.0 \mathrm{c}$ & $0.2 \mathrm{ab}$ & $1.0 \mathrm{c}$ & --- \\
\hline$-\mathrm{GF}+\mathrm{FO}$ & $37.9 \mathrm{abc}$ & $8.0 b c$ & $1.0 \mathrm{c}$ & $0.2 \mathrm{ab}$ & $1.6 \mathrm{bc}$ & $18.5 \mathrm{~b}$ \\
\hline$+\mathrm{GF}-\mathrm{FO}$ & $39.5 \mathrm{abc}$ & $7.9 \mathrm{bc}$ & $2.6 \mathrm{a}$ & $0.3 \mathrm{a}$ & $1.0 \mathrm{c}$ & -.. \\
\hline$+\mathrm{GF}+\mathrm{FO}$ & $35.4 \mathrm{bc}$ & $6.9 \mathrm{c}$ & $2.6 \mathrm{a}$ & $0.3 \mathrm{a}$ & $1.6 \mathrm{bc}$ & $17.5 \mathrm{~b}$ \\
\hline
\end{tabular}

${ }^{2}$ Ratings are based on the percent of root segments colonized by GF and range from 1 (no infection) to 5 ( $>75 \%$ of the root segment infected).

yRating system ranges from 1 to 5 and reflects the percentage of the root system affected by lesions or reddening.

${ }^{x}$ (Number of propagules/g of soil +0.5$)^{1 / 2}$.

row spaces. These plants also exhibited more shoot collapse (crown rot symptom) than nonmycorrhizal plants.

Our greenhouse studies were conducted at a soil P level that had previously yielded similar growth responses in mycorrhizal and nonmycorrhizal asparagus seedlings. Because plant growth was kept uniform, differences in disease ratings were considered to be primarily due to GF-pathogen interaction, as opposed to a secondary effect due to improved growth. Growth of waterstressed plants was not affected by either mycorrhizal or FO inoculation, and their mycorrhizal infection ratings were not significantly different than well-watered mycorrhizal, nonFO treatments. It is possible that asparagus, because it already possesses xerophytic characteristics, does not respond to mycorrhizal colonization under drought stress, as do other plants (Augé et al., 1986; Nelsen and Safir, 1982; Safir et al., 1971). Wilcox-Lee (1987), in a study of the effect of soil matric potential on growth of asparagus, found that asparagus is capable of maintaining a high relative water content, despite prolonged exposure to the same low soil matric potentials maintained in this study.

Our greenhouse results are similar to the results of Caron et al. (1985), who showed that tomato plants inoculated with both the VAM fungus G. intraradices and the root pathogen FO $\mathrm{f}$. sp. radicis-lycopersici had less root necrosis and lower pathogen population levels than plants inoculated with the pathogen alone. The differences in FO populations and disease ratings in both our field and greenhouse studies were apparently unrelated to final plant tissue P levels. Caron et al. (1986b) also found that increased substrate $\mathrm{P}$ and tomato tissue $\mathrm{P}$ levels were unrelated to the decreased fusarium infection and Fusarium populations associated with VAM fungal root colonization. In our field study, asparagus plants that were mycorrhizal before transplanting or subjected to high soil $\mathrm{P}$ had lower tissue $\mathrm{P}$ concentrations than noninoculated controls in the 14th month of growth. However, we believe that tissue P measurements need to be taken throughout the experiment to determine whether changes in tissue concentration are mediated by VAM fungal colonization.

Mycorrhizal colonization of asparagus infected with FO (in the greenhouse) may have been lower than that of noninfected mycorrhizal plants because damage by FO could have reduced the supply of carbohydrate to the mycorrhizal fungus (Cooper, 1984). At low soil matric potentials, FO inoculation did not affect mycorrhizal colonization of asparagus. In addition, these plants were less diseased than well-watered plants infected with both fungi. These results are similar to those of Bååth and Hayman (1983), who found a reduction of VAM fungal colonization when tomato plants were inoculated with a VAM fungus before the pathogen Verticillium albo-atrum. The factors controlling the effects of VAM fungal colonization on disease development and vice versa are not completely understood. The situation is further complicated by the variable effects of watering regimes on Fusarium growth and its ability to cause disease (Cook, 1973). The varying results of studies involving VAM and fungal pathogen interactions may be largely a function of the experimental system used, the timing of data collection, and the organisms involved.

\section{Literature Cited}

Augé, R.M., K.A. Schekel, and R.L. Wample. 1986. Greater leaf conductance of well-watered VA mycorrhizal rose plants is not related to phosphorus nutrition. New Phytol. 103:107-116.

Bååth, E. and D.S. Hayman. 1983. Plant growth responses to vesicular-arbuscular mycorrhiza. XIV. Interactions with Verticillium wilt on tomato plants. New Phytol. 95:419-426.

Bartlett, G.R. 1959. Phosphorus assays in column chromatography. J. Biol. Chem. 234:466-468.

Caron, M., J.A. Fortin, and C. Richard. 1985. Influence of substrate on the interaction of Glomus intraradices and Fusarium oxysporum (f. sp. radicis-lycopersici) on tomato. Plant\& Soil 87:233-239.

Caron, M., J.A. Fortin, and C. Richard. 1986a. Effect of inoculation sequence on the interaction between Glomus intraradices and $F u$ sarium oxysporum (f. sp. radicis-lycopersici) in tomatoes. Can. J. Plant Pathol. 8:12-16.

Caron, M., J.A. Fortin, and C. Richard. 1986b. Effect of phosphorus concentration and Glomus intraradices on fusarium crown and root rot of tomatoes. Phytopathology 76:942-946.

Caron, M., J.A. Fortin, and C. Richard. 1986c. Effect of Glomus intraradices on infection by Fusarium oxysporum (f. sp. radicislycopersici) in tomatoes over a 12-week period. Can. J. Bot. 64:552556.

Chang, D.C.N. 1985. Responses of asparagus seedlings to three Glomus endomycorrhizal fungi. Proc. 6th North Amer. Conf. on Mycorrhizae, Bend, Ore., June, 1984. p. 369.

Cook, R. 1973. Influence of low plant and soil water potential on diseases caused by soil-borne fungi. Phytopathology 63:451-458.

Cooper, K.M. 1984. Physiology of VA mycorrhizal associations, p. 
155-186. In: C.L. Powell and D.J. Bagyaraj (eds.). VA mycorrhiza. CRC Press, Boca Raton, Fla

Damicone, J.P. and W.J. Manning. 1985. Frequency and pathogenicity of Fusarium species isolates from 1st year asparagus grown from transplants. Plant Dis. 69:413-416.

Damicone, J.P., D.R. Cooley, and W.J. Manning. 1981. Benomyl in acetone eradicates Fusarium moniliforme and Fusarium oxysporum from asparagus seed. Plant Dis. 65:892-893.

Davis, R.M., J.A. Menge, and D.C. Erwin. 1979. Influence of Glomus fasciculatus and soil phosphorus on verticillium wilt of cotton. Phytopathology 69:453-456.

Endo, R.M. and E.C. Burkholder. 1971. The association of Fusarium moniliforme with the crown rot complex of asparagus. Phytopathology 61:891.

Evans, T.A., G.R. Safir, and C.T. Stephens. 1985. Vesicular-arbuscular mycorrhizal fungi and their importance in asparagus decline. Proc. 6th Intl. Asparagus Symp. p. 399. (Abstr.)

Graham, K.M. 1955. Seedling blight. A fusarial disease of asparagus. Can. J. Bot. 33:374-400.

Grogan, R.G. and K.A. Kimble. 1959. The association of fusarium wilt with the asparagus decline and replant problem in California. Phytopathology 49:122-125.

Hoddupp, R.M. 1983. Investigation of factors which contribute to asparagus (Asparagus officinalis L.) decline in Michigan. MS Thesis, Michigan State Univ., East Lansing.

Hussey, R.B., R.L. Peterson, and H. Tiessen. 1984. Interactions between vesicular-arbuscular mycorrhiza and asparagus. Plant \& Soil 79:403-416.

Johnston, S.A., J.K. Springer, and G.D. Lewis. 1979. Fusarium moniliforme as a cause of stem and crown rot of asparagus and its association with asparagus decline. Phytopathology 69:778-780.

Komada, H. 1975. Development of a selective medium for quantitative isolation of Fusarium oxysporum from natural soil. Rev. Plant Protection. Res. 8:114.

Nelsen, C.E. and G.R. Safir. 1982. Increased drought tolerance of mycorrhizal onion plants caused by improved phosphorus nutrition. Planta 154:407413.
Nelson, P.E., T.A. Toussoun, and W.F.O. Marasas. 1983. Fusarium species: An illustrated manual for identification. Pennsylvania State University Press, University Park, Pa.

Ohms, R.E. 1957. A flotation method for collecting spores of a phycomycetous mycorrhizal parasite from soil. Phytopathology 47:751752 .

Phillips, J.M. and D.S. Hayman. 1970. Improved procedures for clearing roots and staining parasitic and vesicular-arbuscular mycorrhizal fungi for rapid assessment of infection. Trans. Brit. Myc. Soc. 55:158161.

Powell, C.L1. and D.J. Bagyaraj. 1983. VA mycorrhizae and asparagus. Proc. Agron. Soc. N.Z. p. 107-109.

Powell, C.Ll., D.J. Bagyaraj, G.E. Clark, and K.I. Caldwell. 1985. Inoculation with vesicular-arbuscular mycorrhizal fungi in the greenhouse production of asparagus. N.Z. J. Agr. Res. 28:293-297.

Safir, G.R., J. Boyer, and J.W. Gerdemann. 1971. Mycorrhizal enhancement of water transport in soybean. Science 172:581-583.

Schönbeck, F. and H.W. Dehne. 1977. Damage to mycorrhizal and non-mycorrhizal cotton seedlings by Thielaviopsis basicola. Plant Dis. Rptr. 61:206-207.

Stephens, C.T., S.W. Garrod, and W.H. Elmer. 1985. A comparison of techniques for evaluating Fusarium resistance in asparagus. Proc. 6th Intl. Asparagus Symp. p. 156-167.

Takatori, F., J.I. Stillman, and F.D. Souther. 1970. Asparagus yields and plant vigor as influenced by time and duration of cutting. Calif. Agr. 24(4):8-9.

Takatori, F., J.I. Stillman, and F.D. Souther. 1974. Influence of planting depth on production of green asparagus. Calif. Agr. 28(1):4-5.

VanBakel, J.M.M. and J.J.A. Kerstems. 1970. Root rot in asparagus caused by Fusarium oxysporum f. sp. asparagi. Neth. J. Plant Pathol. 76:320-325.

Wilcox-Lee, D. 1987. Soil matric potential, plant water relations, and growth in asparagus. HortScience 22:22-24.

Zambolim, L. and N.C. Schenck. 1983. Reduction of the effects of pathogenic root-infecting fungi in soybean by the mycorrhizal fungus, Glomus mosseae. Phytopathology 73:1402-1405. 